University of Nebraska - Lincoln

DigitalCommons@University of Nebraska - Lincoln

Investigations of the Ichthyofauna of

Nicaraguan Lakes

Papers in the Biological Sciences

1976

Derivation of the Freshwater Fish Fauna of Central America

George S. Myers

California Academy of Sciences

Follow this and additional works at: https://digitalcommons.unl.edu/ichthynicar

Part of the Aquaculture and Fisheries Commons

Myers, George S., "Derivation of the Freshwater Fish Fauna of Central America" (1976). Investigations of the Ichthyofauna of Nicaraguan Lakes. 9.

https://digitalcommons.unl.edu/ichthynicar/9

This Article is brought to you for free and open access by the Papers in the Biological Sciences at DigitalCommons@University of Nebraska - Lincoln. It has been accepted for inclusion in Investigations of the Ichthyofauna of Nicaraguan Lakes by an authorized administrator of DigitalCommons@University of Nebraska Lincoln. 


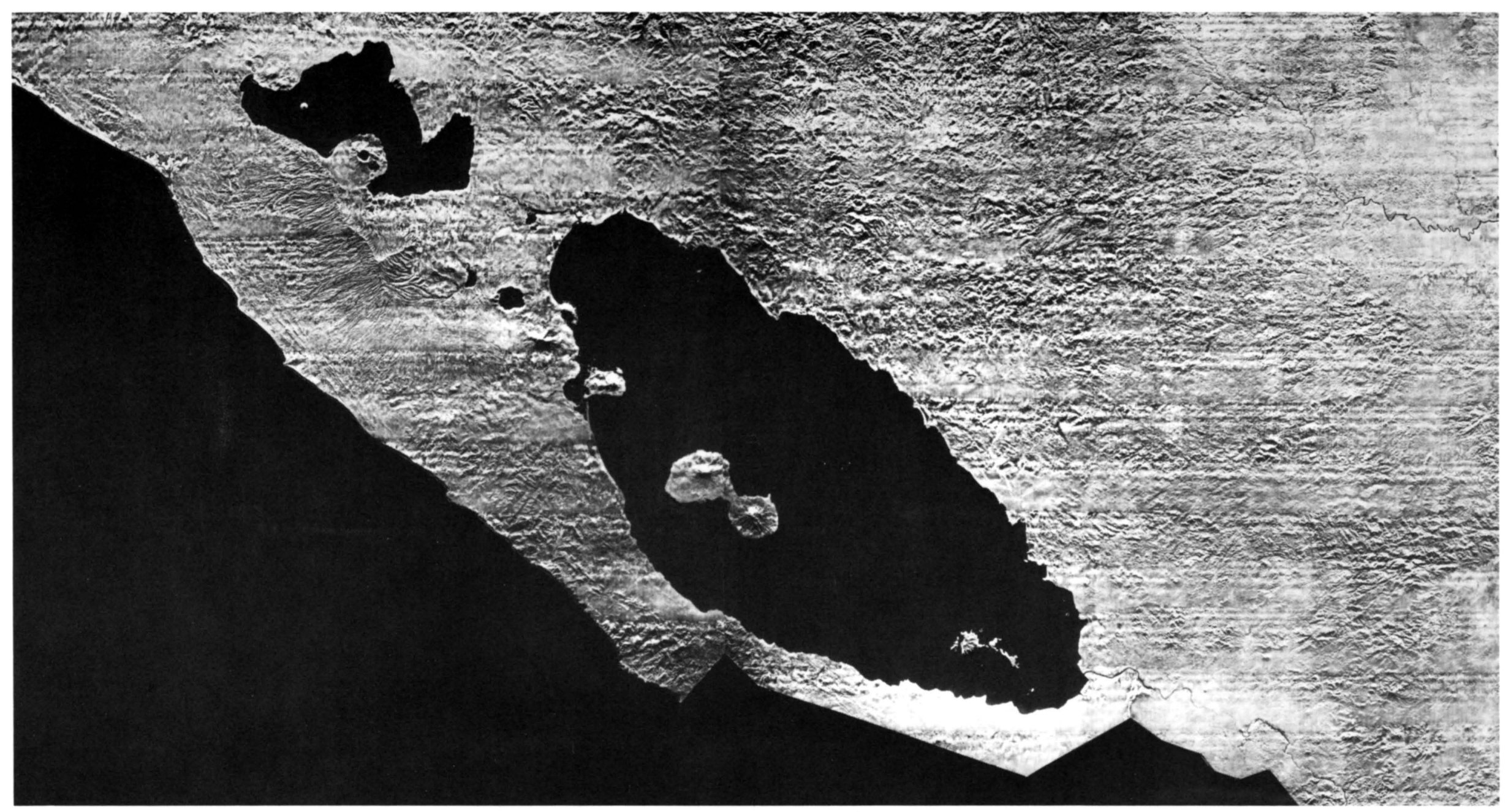

Side looking radar mosaic of research area taken from aircraft at about 40,000 feet. Lake Managua at upper left; Lake Nicaragua with Río San Juan emptying at lower right. Data acquisition by Westinghouse. Courtesy Instituto Geográfico Nacional de Nicaragua. 
Made in United States of America

Reprinted from CopeIA, 1966, No. 4, December 23

pp. $766-773$

\title{
Derivation of the Freshwater Fish Fauna of Central America George S. Myers
}

\begin{abstract}
The nature, composition, and evolution of Central American freshwater fish groups are discussed in relation to the history and derivation of the faunal elements. It is concluded that the entire area between the Isthmus of Tehuantepec and eastern Panamá was and always had been devoid of primary (obligatory) freshwater fishes prior to the very late Tertiary. Instead, secondary freshwater fishes evolved in this area during the Neogene and perhaps for a longer period, the Poeciliidae having probably had a longer history within the area than the Cichlidae. In the late Tertiary a very few North American immigrants entered the area from the north, and towards the end of the Pliocene the closing of the very ancient Panamá sea gap permitted an influx of South American primary types. Most of these have not yet gotten past Costa Rica, but a few aggressive characids have reached Guatemala or southern México and one has reached Texas. It follows that the rich South American primary freshwater fish fauna could not have been originally derived from or through Central or North America, and continental drift (not here discussed in detail) is suggested to explain South American-African similarities.
\end{abstract}

$\mathrm{M}^{\mathrm{y}}$ $Y$ purpose in this paper is to outline, in a very general way, what the present distribution and character of the freshwater fishes of Central America south of the Isthmus of Tehuantepec appear to demonstrate in regard to their geographical derivation as they evolved and dispersed. It is common in studies of this kind to examine the geological evidence in some detail and to attempt to correlate the paleogeographical findings of geologists with the present distributional picture of the organisms concerned. So far as possible, I have not done so. Perhaps as much time has been wasted in attempting to make dispersional patterns of plant and animal groups fit paleogeographical maps published by geologists as biogeographers have wasted in drawing imaginary land-bridges with no geological evidence to back them.

Central America is not as well known, geologically, as North America. Moreover, paleogeographical maps are rarely very exact, for they not only combine a considerable time span into one map, but also are based upon correlations which later work often shows to have been inexact. Finally, biogeographical conclusions are often in part based upon geological conclusions, and are then again cited by geologists as evidence, producing circular reasoning of no mean sort. I have tried to let the fishes tell their story, within only the most general of geological and geographical limits. There are two general books on the geology of the region (Schuchert, 1935; and Weyl, 1961), and these summarize most of the important points.

\section{Composition of the Fish Fauna}

Dr. R. R. Miller (1966) has compiled a list of the fishes known from fresh water between the Isthmus of Tehuantepec and the Colombian border of Panamá. In my totals, I have added a very few still undescribed 
forms which I know to have been collected by Professor Rivas and Dr. Rosen. With these additions, I find a total of 446 species known to me from the area. Of these, 104 are primary freshwater fishes, 165 are secondary species, and 187 are peripheral forms. Of the peripheral species, a good many are what I would call sporadic, that is, which enter fresh water from the sea in river mouths, or occasionally even spend much time away from the sea. Among these are the tarpon and the bull shark. These peripheral freshwater fishes do not concern us at the moment. I wish first to consider the core of the freshwater fauna, the primary forms, most or all of which cannot survive long in sea water of normal salinity.

The 104 species of primary freshwater species belong to 18 families, the largest of which (in our area) is the Characidae, with 42 species. Second is the catfish family Pimelodidae with 23 species, and third is the catfish family Loricariidae, with 14 species. Other families are: Catostomidae (2 species), Erythrinidae (2), Gasteropelecidae (1), Parodontidae (2), Ctenoluciidae (1), Curimatidae (1), Lebiasinidae (2), Gymnotidae (2), Apteronotidae (4), Ictaluridae (1), Auchenipteridae (1), Ageneiosidae (1), Trichomycteridae (2), Callichthyidae (I), and Astroblepidae (1).

However, such totals are misleading if one does not consider the areas inhabited by the fishes. Of the 18 families and 104 species of primary freshwater fishes, two-thirds of the families (12) and nearly three-fourths of the species (74) are found only in Costa Rica and Panamá-that small and narrow part of Central America adjacent to South America. Northwards, from the Costa Rican-Nicaraguan border to the Isthmus of Tehuantepec, only 5 families and 27 species of primary freshwater fishes are known! This is a remarkable fact.

Among the 165 secondary freshwater fishes, which have some tolerance for normal sea water, no such concentration of the majority of the species in the south is noticeable. The more northerly areas are much larger and, as would be expected, have more species. In listing the number of species following each family, I give first the total number of species known for the entire area, followed by the number found only north of Costa Rica: Lepisosteidae (1-1), Cyprinodontidae (2518), Poeciliidae (56-about 34), Anablepidae (1-1), Cichlidae (83-71), Synbranchidae (2-
1). This is somewhat inexact, for several species are found in Costa Rica and also northward into Nicaragua or beyond.

Returning to the primary fishes, it is notable that all of them are ostariophysanscharacoids, gymnotoids, cyprinoids, and catfishes. This also is a remarkable fact. In all other large continental areas in which ostariophysans form a sizable part of the freshwater fish fauna, they are accompanied by at least a few other types of primary (obligatory) freshwater fishes, such as the sunfishes and true perches in North America.

The most startling fact of all is the extreme poverty, in primary freshwater fishes, of what may be called middle Central America-the area between Costa Rica and Tehuantepec. In no other reasonably extensive continental area on earth where cypriniform fishes occur naturally are they (and other primary freshwater fishes) so few in species and so greatly outnumbered by the species of the secondary and even of the peripheral group. The freshwater fish fauna of middle Central America is without parallel in this regard.

Indeed, one might call this great region, from Tehuantepec to the Costa Rican tributaries of Lake Nicaragua, an area of vacuum, or near-vacuum, of primary freshwater fish stocks (Myers, 1963:20). I believe the anomaly to be rather simply explainable, but this simple explanation has far-reaching consequences. Not only does it deeply affect the theories of Darlington (1957) on continental relationships and fish dispersal, but also it deeply affects the conclusions of the only modern ichthyologist who has attempted to utilize the theory of continental drift to explain freshwater fish dispersal (Kosswig, 1944). However, in order to give my explanation, I must make a few observations on ostariophysan ecology and evolution.

\section{Ostariophysan Ecology and Evolution}

What I have to say on these subjects is very brief, for I am presenting the subject in more detail elsewhere. First, I wish to point out some facts of characoid and cyprinoid ecology and evolution that I believe will be accepted because most ichthyologists know them, even though they have rarely or never been stated.

The characoids (Characidae and their close relatives) and the cyprinoids (Cyprinidae and their close relatives) have a generally com- 
plementary distribution, except in Africa, where both occur. Together, they form the order Cypriniformes (see Greenwood, Rosen, Weitzman, and Myers, 1966), which, together with the catfish order Siluriformes, comprises the superorder Ostariophysi. Wherever they occur naturally in any numbers, save in Central America and certain endemic lake faunas, cypriniform fishes have become more speciose than other groups, especially in the smaller species. Everywhere in fresh waters, except in Australia, species of little cyprinoids or characoids are the principal forage fishes on which larger predators feed. They swarm in the lowland rivers and in the highland brooks. Wherever larger predators belonging to other orders are few or absent, and occasionally when they are fairly numerous, the cypriniform fishes themselves have evolved large and important predatory forms (Salminus, Brycon, and Serrasalmus in South America; Hydrocynus and large Barilius in Africa; Elopichthys and Luciobrama in China; Ptychocheilus in western North America). They are the most successful, aggressive, numerous and all-pervading of freshwater fishes. Cyprinidae have probably been present in North America only since the Early Miocene (Myers, 1938), but they now form the preponderant element of the fauna. In Africa, where Cyprinidae entered (probably in the Miocene or Pliocene) a continent already inhabited by the other large cypriniform group, the characoids, the cyprinids have become the more numerous group, in species and in individuals. ${ }^{1}$ But they by no means swamped-out the older African characoids, numbers of which, both large and small, still survive. Even in the remarkably rich endemic African lake faunas, composed mostly of the highly preadapted Cichlidae, small cypriniform fishes (e.g., Engraulicypris) tend to form the bulk of the primary forage fishes.

Why are the species of Cypriniformes so few in middle Central America? Several explanations occur. One is that a large fauna of cichlid species, which is present equally in

\footnotetext{
1 The relative newness of Cyprinidae in Africa is demonstrated beyond reasonable doubt by the small number of African genera, nearly all of which are identical with dominant genera of the far richer and more diverse cyprinid fauna of Asia. In other words, as in any intercontinental, filter-bridge invasion, it was almost entirely the common, dominant Asiatic genera which colonized Africa. Also, there can be no doubt in this instance that the transfer was a one-way affair, for none of the older African groups reached Asia.
}

the African lakes and in Central America, including many predatory species in each, cuts down the evolutionary rate of smaller cypriniform fishes. This is a demonstrably impossible explanation. The rivers of both South America and Africa are rich in genera and species of cichlids, many of them highly predatory, but the number of species of cypriniform fishes in the same rivers is far greater. Only in lakes, to which cichlids are much better adapted than are cypriniforms, can such a theory perhaps be considered to have applicability. Other explanations, involving periodic destruction of the fish fauna by the admittedly high incidence of vulcanism in Central America, or periodic marine transgressions of large extent, cannot be entertained, because such catastrophes would also have involved the far more speciose cichlids and poeciliids in the same areas.

The only acceptable explanation is that already suggested by myself (Myers, 1938) the cypriniform fishes in middle Central America are, geologically speaking, very new to the area. They have not yet had time to evolve many endemic species or genera. And they have penetrated into the area far more recently than the more speciose Central American Poeciliidae and Cichlidae.

One can make such a statement purely on the basis of the literature, but seeing the fauna in the field is even more convincing. Four years ago I collected in the basin of Lake Nicaragua, Lake Managua, and the Rio San Juan. The rotenone rarely or never brought up more than four species (usually only two or three) of cypriniform fishes at any one place-a couple of small characids (usually a Roeboides, an Astyanax and a large predatory Brycon, up to nearly a yard in length)-mixed with a much more varied assortment of Cichlidae, a gymnotus, a Rhamdia, some poeciliids, and some gobies. Garpike were present; also tarpon and sharks. But it was clear that at least $50 \%$ of the biomass or weight of fish present in the streams must have been composed of the three or four species of Characidae! This was certainly true if one adds to the characids the biomass of pimelodid catfishes presentusually a single species of Rhamdia. In other words, the few species of newcomers, both characids and Rhamdia, are today by far the most numerous fishes in the streams. These ostariophysans are obviously in the early stages of taking over an area newly opened 
to them. No other explanation appears to be possible.

\section{Derivation of the faunal Elements}

Aside from peripheral groups, the only families of either primary or secondary freshwater fishes present in middle Central America that were unquestionably derived from North America are the garpike (Lepisosteidae), with one species extending as far south as the Costa Rican tributaries of Lake Nicaragua; the suckers (Catostomidae), with two species reaching southern Mexico and Guatemala; and the North American catfish (Ictaluridae), with one species extending from southern Mexico into Guatemala and British Honduras. The derivation of these is unquestioned; they came from the north. So, perhaps, did the Cyprinodontidae and Poeciliidae.

At the southern end, the relatively rich Panamanian fauna of primary fishes is all South American. Many species are identical with those of the Rio Atrato and even the Rio Magdalena in Colombia, but, as would be expected, even the apparently rich Panamanian fauna is merely a pale reflection of the greater richness of the South American rivers.

Leaving aside the Panamá-Costa Rica fauna at the south, the few North American elements, and, for the moment, the Cyprinodonts, Cichlidae, and marine derivatives, there seems to be no doubt that all the rest of the faunal elements of middle Central America came from the south-evidently from South America. Astyanax, Hyphessobrycon, Roeboides, Brycon, Gymnotus, and Rhamdia are all generalized, widespread genera in South America. They are precisely the types that would be expected to be in the forefront of any invasion of newly opened territory, because they (and relatively few others) have developed South American ranges almost or quite coextensive with the ranges of the families or subfamilies to which they belong. They found no climatic barriers in their invasion of the wholly tropical area of middle Central America, a type of barrier which undoubtedly acted as a deterrent to most North American groups moving southward. The South American genera which have gotten no farther north than Panamá or Costa Rica, although also mostly members of relatively widespread genera, are, on the whole, less able to make use of swift water streams than the six genera mentioned above, while some have a rather highly specialized ecology.

If one includes all of México as well as Central America, there are nearly a hundred species of Cichlidae in the area, and the group has obviously had a special center of evolution in this region. However, South America has more cichlid species and far more genera. Nearly all the endemic Central American forms belong to the common South American genus Cichlasoma. There can be little doubt that this element of the fauna arrived in Central America relatively recently, but probably prior to the invasion of the Characidae. In the ostariophysan vacuum of middle Central America, before the advent of characids, relatively rapid evolution of Cichlasoma species obviously went on, both in streams and in lakes.

Less numerous in species, but more diverse in Central American genera than the cichlids, the Poeciliidae would appear to have had a longer period for evolution in the region than the Cichlidae. Apparently limited to rather small physical size by heredity, the poeciliids nevertheless evolved such a rapacious predator as Belonesox in middle Central America, as well as mud-eaters, surfacefilm feeders, alga-scrapers, and insectivorous forms. The entire gambusine group, as well as Pseudoxiphophorus, tends to be predaceous on fishes smaller than themselves, including the young of larger species. I doubt that poeciliid forms of such diverse specialization would have been evolved had there been much competition from other families.

Parenthetically, I find it somewhat difficult to talk about certain generic evolutionary and geographic trends according to the new classification of Rosen and Bailey (1963). For example, all or nearly all species of the old (and more restricted) genera Poecilia, Mollienesia, Limia, and Xiphophorus appear to be averse to soft, acid water, and to need some dissolved calcium carbonate or chloride, while Lebistes, Micropoecilia, Pamphorichthys, and Pseudopoecilia tend to inhabit soft, acid water by preference. In general, poeciliids appear to be few in species and in individuals in the great soft water areas of Guiana and Amazonia, although this may be related to the diversity and numbers of characoid fishes in such areas. However both soft water and characoid predominance have 
probably persisted in the Guiana-Amazon region for the entire Cenozoic, and if the poeciliids had a South American origin, one or the other or both of these must have constituted limiting factors to their northward dispersal. However, now that a close ally or member of the Cnesterodontini has been found in Guatemala by Rosen, all of the main generic groups except the Guianan Tomeurinae are known from middle Central America, and it seems reasonable to conclude that this area has formed the main evolutionary center of the group.

One more possible factor in regard to poeciliid evolution needs to be mentioned. If the poeciliids were present and evolving in middle Central America prior to the advent of South American cichlids and ostariophysans, invasion by these often larger and more powerful newcomers might have tended to cut down the species numbers and diversity of the small, weak-swimming poeciliids. At least some special ecological niches or biotopes formerly occupied by poeciliids, but for which the newcomers were better adapted, would have been rapidly filled by the invaders, with concurrent disappearance of such poeciliids. I suspect that this has happened in our area, perhaps to some larger, stream-inhabiting poeciliids, leaving the many smaller poeciliids, as in North and South America, only in what might be termed peripheral habitats.

The Picture of Fish Evolution AND DISPERSAL

The picture that emerges so strongly from careful evaluation of the elements and nature of the freshwater fish fauna of middle Central America may be summarized as follows:

1. Ostariophysan fishes of the primary freshwater type are relatively new to the area and were never present there previous to the beginnings of the invasions which we now see in progress. There are no ancient relicts of this group present. If primary cypriniform fishes had been present at any previous time, especially in the earlier Tertiary, pockets or remnants discordant with the members of the late invasion by dominant South American genera would almost surely have remained. The only endemic genera of Characidae present are Bramocharax (two species in Nicaragua and one still to be described from Guatemala) and a localized and, so far, undescribed genus more or less intermediate be- tween Bramocharax and Astyanax (collected by Rivas). The teeth and mouth structure of Bramocharax give evidence of derivation from Astyanax, perhaps not too long ago, and discovery of the new intermediate genus lends strong support to the origin of Bramocharax from the earliest Astyanax invaders. Rhamdia, perhaps the most ubiquitous and ecologically generalized South American catfish genus, undoubtedly arrived concurrently with the characids. Invasions by primary freshwater fishes of North America type were confined to two species of the catostomid genus Ictiobus and one species of the catfish genus Ictalurus, and these have barely reached the northern part of middle Central America. Considering what we know of the rates of ostariophysan evolution, it would appear highly probable that the entire area of middle Central America constituted a region of primary ostariophysan vacuum until the Late (and possibly very late) Tertiary. In a continental area of such extent, it is to the highest degree improbable that Early Tertiary primary ostariophysans were present in middle Central America, only to be wiped out by vulcanism or marine transgressions.

2. It follows that middle Central America, and probably also Costa Rica and Panamá, must have been protected from invasion by primary freshwater fishes from the north and south for a very long period of geological time. Highly effective barriers to invasion must have been present to the south and probably in the north, and these barriers were almost certainly of a geographical (geological) character in the south. The climatic factor of the beginning of tropical climates just north of Tehuantepec has undoubtedly played a role in the north, in practically excluding dominant North American cyprinoids from the area to the present day. A climatic factor would not have been operative at the southern barrier. The fishes, of the fossils of which we know next to nothing, do not date the breakdown of the southern barrier to primary freshwater fishes. All the fish evidence alone can do is to indicate that the breakdown in the south was almost certainly of Late Tertiary age.

3. Before the breakdown of the southern barrier, the Central American fish fauna lacked all elements of a primary freshwater fish fauna, except perhaps for two or three northerly forms in the north. It was composed of peripheral invaders from the sea 
(gobies, centropomids, clupeids, atherinids, etc.) and of two widely different groups of secondary freshwater fishes-cichlids and cyprinodonts, which are known to be able occasionally to use the sea for dispersal, either across open sea barriers or along coasts. Even today these elements are more numerous than the primary fishes in number of species. Evidence from the diversity of the fishes themselves strongly indicates that the cyprinodonts, especially the poeciliids, were there and evolving for a considerable period before the arrival of cichlids, and the invasion of the latter almost certainly preceded that of the primary ostariophysans, which are now finally beginning to overwhelm the cyprinodont and cichlid diversity into which they were injected. By continental standards, the fauna is still a highly unbalanced one. Cichlid morphological conformity to the Cichlasoma pattern in Central America is strong evidence that the Central American cichlids originated in South America and that the subsequent evolution of Cichlasoma and its close relatives in the Central American ostariophysan vacuum has been rapid and geologically of no very great age. Our principal fossil evidence consists of a single Miocene cichlid from the Greater Antillean island of Hispaniola. Presumably cichlids in Central America have been there as long and probably longer than in the West Indies, although this is not necessarily true. The Miocene fossil may have represented a single early overseas colonization from South America. However, if it represents a form derived from Central America, Cichlasoma probably entered Central America as long ago as the Early Miocene (or before) thus pushing the beginnings of poeciliid evolution in Central America probably into the Oligocene. However, such reasoning on the basis of a single extralimital fossil is highly dangerous.

\section{Geological Correlations}

It now remains to be seen how the known geological facts fit into the picture as painted from the fish evidence. I shall not go deeply into the geology, for I feel that the time is not ripe for such correlation, and it should be made by geologists or paleontologists. However, it can be said that the geological evidence, and especially recent paleontological evidence derived from mammals, fits in with the fish evidence very well (see especially
Schuchert, 1935; Weyl, 1961; Patterson and Pascual, 1963).

It appears that a sizable core of middle Central America, comprising Honduras, El Salvador, and large adjacent parts of Guatemala and Nicaragua, has remained unflooded by the sea since the Paleozoic. However, even if this area did not emerge until the earlier Neogene, the picture of fish distribution would not be changed in any important way, for certainly some sizable sections of middle Central America must have been emergent at any particular time. To the northward, especially in the Tehuantepec region, there was considerable marine transgression during the Cenozoic, which kept the Yucatán peninsula under water during most of that time. In general, the Isthmus of Tehuantepec was usually much narrower than at present, and there was Atlantic-Pacific sea connection across it during the Miocene and Pliocene, and perhaps at earlier times. Also, there was oceanic connection across southern Nicaragua during the Oligocene and Miocene, and perhaps at other times.

If the Panamá interocean passage was ever bridged by dry land previous to the Pliocene, that bridging was far back in the Mesozoic. Recent geological work in Colombia makes it fairly certain that the interocean passage was not across Panamá but across northwestern Colombia. It was a wide break and obviously a thoroughly effective one insofar as the northward movements of South American primary freshwater fishes is concerned. Obviously, none got into Panamá until the break was closed.

The dating of the final closing of the Panamanian-Colombian gap has been the result of recent work by mammalian paleontologists. Patterson and Pascual (1953:146) said: "The long isolation of South America ended in the late Pliocene (perhaps earliest Pleistocene) when the last great episode of Andine uplift began. The Americas were united at Panama by a continuous if narrow bridge and a great exchange of mammals got under way." The importance of this evidence is great because, of all terrestrial animals, the paleontological history of the mammals has been the most intensely and broadly studied. No fossil evidence derived from other groups of continental organisms is presently nearly as well documented as that from mammals. That there was earlier overwater exchange of mammals between North 
and South America is obvious, but the seabarrier appears to have persisted from at least as early as the Jurassic up to the very end of the Tertiary, and may never have been bridged until the Pliocene.

Primary freshwater fishes, as I have often pointed out (Myers, 1938, 1949) cross seabarriers with much greater difficulty than mammals and amphibians. There is therefore good reason to believe that the invasion of Central America by primary freshwater ostariophysans from South America is quite as young as the character and ecology of the middle Central American fish fauna leads us to believe. The secondary cichlids were probably able to cross the narrowing sea-barrier before the primary ostariophysans got their necessary land bridge. And the poeciliids, if they came from South America, or if they migrated south into South America, were quite as able sea navigators as the cichlids.

\section{BroAdER IMPLICATIONS}

I see no escape from the conclusion that Central America possessed no obligatory freshwater ostariophysans until the Pliocene or even the Pleistocene, since which time the most aggressive and ubiquitous of all characoid genera (Astyanax) has, in a geological sense, raced northward to the Rio Grande, trailed a little more slowly by Hyphessobrycon, Brycon, Roeboides, Gymnotus, and a few others. A cichlid also has reached the Rio Grande, but almost certainly its immediate ancestors had a somewhat longer period in which to get there than the characids had. The three North American primary fishes in Guatemala cannot have been there long.

These conclusions being accepted, it follows that the derivation of the excessively rich South American freshwater fish fauna, especially the cypriniform characoids, from Asian immigrants which filtered through the North and Central American faunas without leaving a trace (Darlington, 1957), cannot be seriously entertained. Cypriniform fishes do not filter through a fauna without leaving traces, as Darlington presumed. They take over continental faunas and tend to "swamp out" other groups, becoming the dominant element of the fauna. And what fossil evidence we have about them indicates that, morphologically and presumably ecologically, they have changed but little since the earliest Cenozoic.

This negation of one of the main points of
Darlington's scheme of primary freshwater fish dispersal inevitably affects his entire world scheme, which presupposes continental or, rather, ocean basin stability. This is not the time or place to enter into these larger questions, which I am considering elsewhere. However, this leaves the South American primary fishes without the possibility of northern derivation during the enormous time period from the earlier Mesozoic to the Pleistocene. I cannot believe that their ancestors came from any northern continent. Inevitably this brings us to explanations of marine derivation during the Cretaceous, which there is growing reason to reject, or to Mesozoic union of South America and Africa, which there is growing reason to accept. ${ }^{2}$ I believe continental drift to be the ultimate answer, and even Darlington (1964) has very recently cautiously come out in favor of drift. I am taking up the problem of drift in relation to fish distribution elsewhere.

\section{Literature Cited}

Dardington, P. J., JR. 1957. Zoogeography: the geographical distribution of animals. John Wiley and Sons, New York, N. Y.

- 1964. Drifting continents and Late Paleozoic geography. Proc. Nat. Acad. Sci. 52:1084-1091.

Greenwood, P. H., D. E. Rosen, S. H. Weitziman, AND G. S. MYers. 1966. Phyletic studies of teleostean fishes, with a provisional classification of recent forms. Bull. Am. Mus. Nat. Hist. 131(4):339-456.

KosswIG, C. 1944 . Kontinentalverschiebungstheorie und Fischverbreitung. C. R. Ann. Arch., Soc. Turque Sci. Phys. Nat. Istanbul 11: 1-28.

MILLER, R. R. 1966. Geographical distribution of Central American freshwater fishes. Copeia 1966(4): 773-802.

Myers, G. S. 1938. Fresh-water fishes and West Indian zoogeography. Ann. Rep. Smith. Inst. for 1937, Wash., D. C. Pp. 339-364.

-. 1949. Salt-tolerance of fresh-water fish groups in relation to zoogeographical problems. Bijdr. Dierk. 28:315-322.

- 1963. The fresh-water fish fauna of North America. Proc. XVI Internat. Congr. Zool. 4:15-20.

Patterson, B. and R. Pascual. 1963. The extinct land mammals of South America. Pro-

\footnotetext{
2 I know of only one attempt by an ichthyologist to explain freshwater fish dispersal by means of continental drift (Kosswig, 1944). Unfortunately, Kosswig was unfamiliar with such important publications bearing on drift as those of du Toit, and he was obviously un acquainted with much of the extensive mammalian and acquainted with much of the extensive mammalian and
other tetrapod evidence. In the face of that evidence, Kosswig's geological timing is so inacceptable that grave doubt is cast upon all features of his ingenious scheme.
} 
gram, XVI Internat. Congr. Zool. Pp. 138148.

Rosen, D. E. And R. M. Bailey. 1963. The poeciliid fishes (Cyprinodontiformes), their structure, zoogeography, and systematics. Bull. Am. Mus. Nat. Hist. 126(1):1-176.

SCHUCHERT, C. 1935. Historical geology of the
Antillean-Caribbean region. John Wiley and Sons. New York, N. Y.

Weyl, R. 1961. Die Geologie Mittelamerikas. Beitr. region. Geol. Erde. Bd. 1, 266 pp.

Division of Systematic Biology, Stanford University, Stanford, California 94305. 